\title{
Memberdayakan Rencana Detail Tata Ruang (RDTR) Kawasan Strategis Hutan Lindung Sungai Wain dan Sungai Manggar Tahun 2015-2035 dalam Mereduksi Ancaman Kelestarian Lingkungan
}

\author{
Adam Maulana ${ }^{1}$ \\ Departemen Perencanaan Wilayah dan Kota \\ Fakultas Teknik, Universitas Diponegoro, Semarang, Indonesia \\ Artikel Masuk : 15 Mei 2016 \\ Artikel Diterima : 9 Juli 2016 \\ Tersedia Online : 31 Agustus 2016
}

\begin{abstract}
Abstrak: Hutan lindung merupakan kawasan strategis berfungsi sebagai tempat perlindungan keanekaragaman hayati dan iklim serta penyeimbang tata guna air. Undang-Undang Nomor 12 Tahun 2012 menjadi dasar bagi Kota Balikpapan untuk menjabarkan Rencana Tata Ruang Wilayah (RTRW) dalam Rencana Detail Tata Ruang (RDTR) kawasan strategis dalam sudut pandang sosial budaya dan lingkungan hidup yang mencakup 3 kawasan strategis, yaitu hutan lindung, pendidikan, serta pemukiman atas air. Konsep pembangunan berkelanjutan yang menitikberatkan pada keseimbangan aspek lingkungan, sosial dan ekonomi menjadi pendekatan makro pada penyusunan rencana detail untuk ketiga kawasan strategis tersebut. Kawasan Hutan Lindung Sungai Wain dan Sungai Manggar saat ini terindikasi terancam keberadaannya di masa depan akibat semakin berkembangnya aktivitas alih fungsi lahan, industri serta penambangan batubara di sekitar kawasan hutan lindung. Artikel bertujuan untuk mengetahui arahan pengembangan yang direncanakan dalam penataan kawasan hutan lindung yang berpotensi mengurangi dampak ancaman di masa yang akan datang. Analisis dilakukan dengan membandingkan strategi penataan ruang pada kawasan hutan lindung Kota Balikpapan dengan indikator pembangunan berkelanjutan oleh Commission of Sustainable Development United Nation. Hasil menunjukkan bahwa pengelolaan kawasan hutan lindung melalui konsep “developmental conservation”. Konsep ini menekankan unsur kolaborasi antara pemerintah sebagai pembuat kebijakan yang mengatur pengembangan aktivitas wisata alam dan masyarakat lokal sebagai stakeholder utama pengembangan pariwisata. Konsep pembangunan berkelanjutan mampu memberikan perlindungan kelestarian hutan lindung dan menghasilkan nilai ekonomi bagi masyarakat sekitar dan pemerintah.
\end{abstract}

Kata Kunci: alih fungsi lahan, hutan lindung, Kota Balikpapan, pembangunan berkelanjutan

Abstract: Protected forest is a strategic area with functions to protect biodiversity and macro climate and to balance water use. The Act No. 12 Year 2012 provides a basis for detailing Balikpapan City spatial plan from general a spatial plan (RTRW) to detailed spatial (RDTR). As a strategic area, it carries out socio-cultural and environmental perspectives covering three

\footnotetext{
${ }^{1}$ Korespondensi Penulis: Departemen Perencanaan Wilayah dan Kota, Fakultas Teknik, Universitas Diponegoro, Semarang Email: adam.maulana16@pwk.undip.ac.id
} 
strategic areas, i.e. protected, education, and settlement in the water areas. Sustainable development concept which focuses on balancing environmental, social, and economic aspects has become a macro approach for preparing the detailed plan for those three strategic areas. Currently, the protected forest areas of Wain River and Manggar River are endangered due to land use change and coal mining industry around. This article aimed to determine the development plan guidance for the protected forest areas in order to reduce the future impacts. The analysis conducted by comparing the spatial plan of protected area forest in Balikpapan to sustainable development indicators developed by the Commission of Sustainable Development United Nations. The results revealed that the management of protected forest areas conducted through the concept of "developmental conservation". This concept was conducted through collaborative role between the government as the regulator for the development of the natural attraction activity and the local communities as the main stakeholder in tourism development. The concept of sustainable development can provide the protection and preservation of the protected forest as well as the generation of economic value for local communities and the government.

Keywords: land use change, protected forest area, Balikpapan City, sustainable development

\section{Pendahuluan}

Kawasan Hutan Lindung Sungai Wain (KHLSW) dan Sungai Manggar (KHLSM) memiliki fungsi penting bagi Kota Balikpapan. Kawasan Hutan Lindung Sungai Wain (KHLSW) berperan penting untuk menjaga kelestarian lingkungan, keanekaragaman hayati, dan kestabilan ekosistem di Kota Balikpapan karena posisinya yang berada di bagian hulu dari Kota Balikpapan. Sementara itu, Kawasan Hutan Lindung Sungai Manggar (KHLSM) menjadi kawasan yang berperan penting untuk menjaga kelestarian alam, seperti ketersediaan sumber daya air baku permukaan dan air tanah serta mencegah terjadinya bencana seperti banjir dan longsor.

Secara administratif, KHLSW terletak di Kelurahan Karang Joang Kecamatan Balikpapan Utara dan Kelurahan Kariangau Kecamatan Balikpapan Barat. KHLSW adalah perpaduan antara objek wisata hutan dan sungai. Hutan yang terdapat di KHLSW terdiri atas hutan primer (hutan asli) dan hutan sekunder (hutan buatan). Hutan buatan yang terdapat di KHLSW merupakan hutan pengganti akibat peristiwa kebakaran hutan yang terjadi pada tahun 1997/ 1998. Berdasarkan Perda RTRW Kota Balikpapan Tahun 20122032, kawasan hutan lindung Sungai Wain memiliki luas 11.184 Hektar (Gambar 1).

Secara administratif, KHLSM terletak di Kecamatan Balikpapan Utara dan Balikpapan Timur dan mencakup 4 kelurahan, yaitu Karang Joang, Manggar, Teritip, dan Lamaru dengan luas 5.000 Ha. Selain sebagai kawasan hutan lindung, KLHSM memiliki Waduk Manggar. Sesuai Surat Keputusan Kementerian Kehutanan No. 267/KPTS - II/ 1996, Waduk Manggar memiliki fungsi pokok sebagai daerah tangkapan air. Salah satu aktivitas di KHLSM adalah pengelolaan air oleh Perusahaan Daerah Air Minum (PDAM) Balikpapan. Aktivitas PDAM Balikpapan memiliki nilai strategis dalam perspektif kepentingan umum. Hal ini ditunjukkan oleh data PDAM Balikpapan tahun 2010 bahwa pada tahun 2009, lebih dari 70.000 pelanggan atau lebih dari $70 \%$ kebutuhan air masyarakat Balikpapan sangat tergantung dengan PDAM Balikpapan.

Pesatnya pembangunan dan perkembangan Kota Balikpapan berdampak positif bagi perkembangan sosial ekonomi masyarakat Balikpapan. Namun demikian, pembangunan Kota Balikpapan mengancam keberlanjutan pembangunan lingkungan. Kelestarian kawasan hutan lindung terancam oleh adanya konversi lahan akibat aktivitas perkebunan masyarakat yang memiliki nilai ekonomis cukup tinggi, seperti tanaman aren, karet, dan buah-buahan. Di sisi lain, aktivitas masyarakat di tepian sungai dan waduk mengganggu 
fungsi sungai serta waduk yang terdapat di kawasan hutan lindung karena kegiatan manusia dalam kawasan sempadan sungai dan danau berpotensi menganggu kelestarian fungsi sungai dan danau, antara lain merusak kualitas air sungai, mengubah kondisi fisik pinggir dan dasar sungai serta mengganggu aliran sungai. Untuk itu, diperlukan pengembangan kawasan melalui konsep pembangunan berkelanjutan. Konsep pembangunan berkelanjutan yang memiliki prinsip keseimbangan antara aspek ekonomi, sosial, dan lingkungan dipilih sebagai pendekatan dalam penyusunan Rencana Detail Tata Ruang (RDTR) Kawasan Strategis Kota Balikpapan. Konsep pembangunan berkelanjutan dipilih karena dianggap dapat menyeimbangkan antara pesatnya pembangunan Kota Balikpapan dengan kelestarian lingkungan Kota Balikpapan yang harus dijaga.

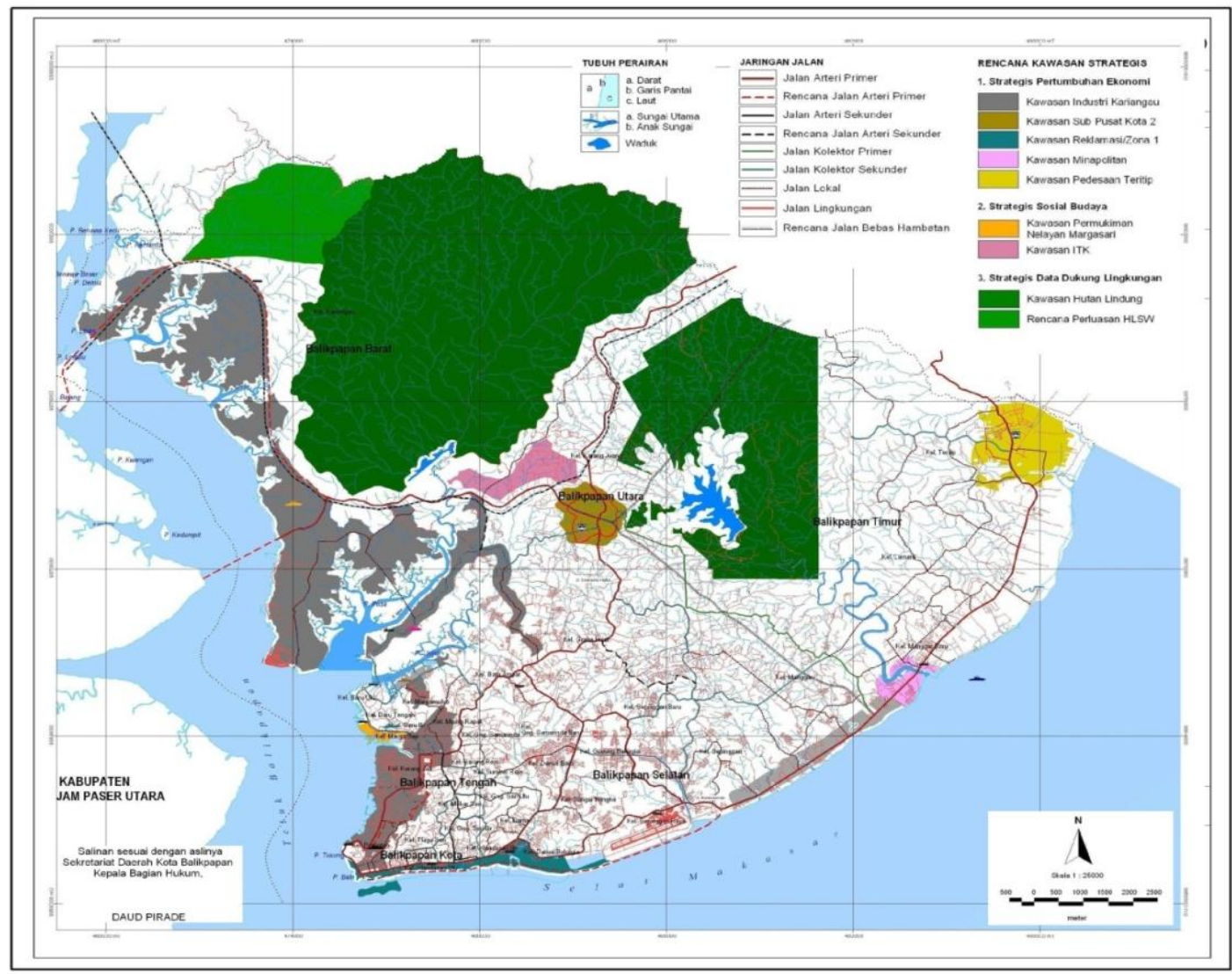

Sumber: RTRW Kota Balikpapan, 2005-2015

\section{Gambar 1. Kawasan Hutan Lindung}

Konsep pembangunan berkelanjutan bertujuan untuk meningkatkan kesejahteraan masyarakat serta memenuhi kebutuhan dan aspirasi manusia (Salim, 1992). Pembangunan berkelanjutan ditujukan untuk mencari pemerataan pembangunan antar generasi pada masa kini maupun masa mendatang. Cleveland (2007) juga menjelaskan mengenai konsep pembangunan berkelanjutan bahwa keseimbangan keberlanjutan antara aspek ekonomi, sosial, dan lingkungan menjadi poin utama (lihat Gambar 2). Konsep pembangunan berkelanjutan menjadi penyeimbang antara kebutuhan peningkatan aspek ekonomi dan aspek lingkungan yang pada praktiknya sering saling melemahkan.

Sebagaimana diungkapkan Fauzi \& Oktavianus (2014); Apriyanto, Eriyatno, Rustiadi, dan Mawardi (2015) bahwa indikator pembangunan mengalami kemajuan di bidang 
ekonomi dan sosial namun tidak untuk lingkungan yang menunjukkan tren penurunan. Lebih lanjut, menurut Sutamihardja (2004) bahwa dalam konsep pembangunan berkelanjutan dimungkinkan terdapat benturan kebijakan dan kebutuhan untuk menggali sumber daya alam guna memerangi kemiskinan dan mencegah terjadinya degredasi lingkungan agar keduanya dapat berjalan seimbang. Untuk itu, menurut Lama dan Job (2014) bahwa dalam memahami konsep pembangunan berkelanjutan pada kawasan yang dilindungi diperlukan pemahaman baik secara politik, lingkungan dan sosial-ekonomi.

Dalam konsep pembangunan berkelanjutan, dari sudut pandang lingkungan, degradasi lingkungan secara lansung dapat menurunkan kualitas hidup masyarakat di sekitarnya, sedangkan konservasi lingkungan dapat berkontribusi positif dalam peningkatan kualitas hidup manusia. Serupa dengan Diaz (2011) yang juga mengungkapkan bahwa penurunan kualitas lingkungan berdampak pada penurunan aspek sosial dan ekonomi. Oleh karena itu, usaha penyediaan, pengaturan, dan pengendalian merupakan hal yang sangat penting (Millenium Ecosystem Assessment, dalam Romagosa, Eagles, \& Lemieux, 2015).

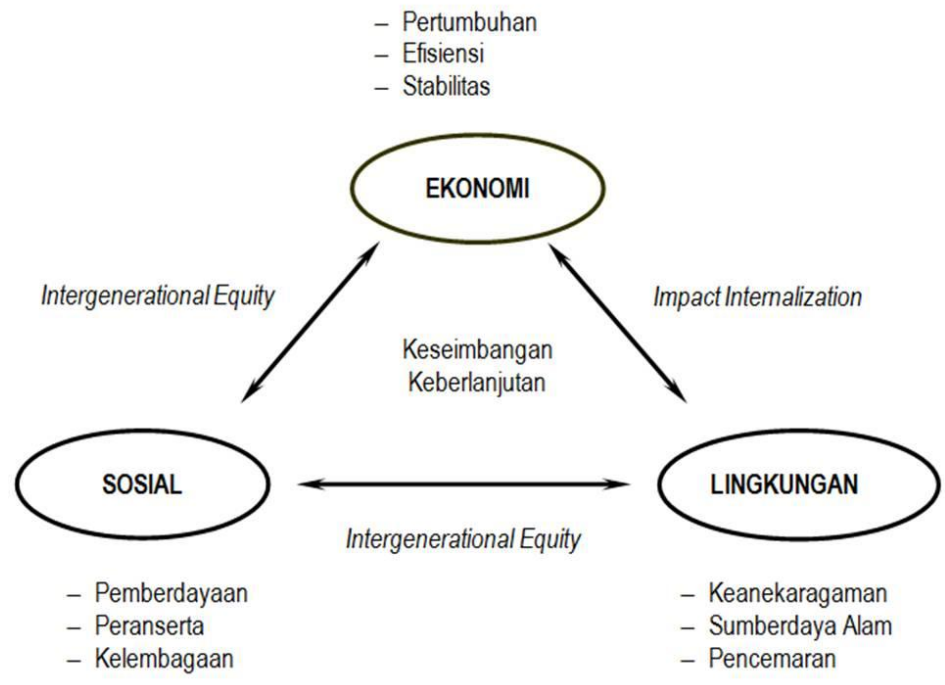

Sumber: Cleveland, 2007

Gambar 2. Konsep Pembangunan Berkelanjutan

Best practice dapat diambil dari upaya pengembangan kawasan hutan lindung di China dengan menggunakan konsep selective commodification and development conservation. Konsep tersebut adalah sebuah strategi pengelolaan hutan lindung melalui pengembangan kawasan wisata hutan lindung yang diatur dan diawasi oleh pemerintah China, namun menjadikan masyarakat sekitar sebagai subyek utama pengembangan. Hal ini dilakukan guna terciptanya keseimbangan antara kelestarian lingkungan serta pengembangan aktivitas wisata. Untuk itu, pemerintah mengatur, mengendalikan, membatasi aktivitas dan akses bahkan merelokasi masyarakat di sekitar kawasan lindung. Setiap kawasan lindung memiliki karakteristik yang unik sehingga strategi yang dilakukan pemerintah untuk dapat mengembangkan kawasan tersebut juga berbeda-beda untuk setiap wilayah (Zinda, 2015). Di sisi lain, upaya pembangunan ekologi di China juga mendapat dukungan dari pemerintah pusat sejak tahun 2000, dimana pemerintah telah secara intensif berinvestasi di kawasan lindung namun tetap memperhatikan keseimbangan ekologi (Yeh, 2009; Li, Li, Zhang, \& Fan, 2013). Salah satu kawasan lindung yang dikelola 
secara berkelanjutan adalah kawasan lindung Zhangjiajie-Wulingyuan. Hutan lindung Zhangjiajie merupakan kawasan wisata hutan lindung yang dipromosikan sebagai hutan lindung pertama di China pada tahun 1982. Perkembangan aktivitas pariwisata memberikan perubahan pada lansekap wilayah, mata pencaharian, dan pemerintahan. Pada tahun 1989, kunjungan turis mencapai 381.500 pengunjung. Pengembangan aktivitas pariwisata berpusat pada usaha kecil yang dilakukan oleh masyarakat sekitar. Perkembangan sektor pariwisata berdampak pada pencemaran lingkungan dan sumber air baku. Menanggapi hal tersebut, pemerintah setempat berupaya membentuk kebijakan baru berupa relokasi masyarakat dan menutup berbagai usaha kecil yang dimiliki masyarakat terkait pariwisata dan hanya mengijinkan dua perusahaan besar mengelola kawasan wisata. Masyarakat mendapatkan kompensasi akibat diambilnya lahan tempat tinggal dan usaha mereka. Hasil dari strategi ini dapat dilihat bahwa pada tahun 2002 sebanyak 59\% pendapatan pajak distrik Zhangjiajie berasal dari sektor pariwisata. Kondisi ini meningkat sekitar 20\% pada awal 1990-an dan pada tahun 2005, sektor pariwisata mampu berkontribusi 54,4\% dari ekonomi produk di distrik Zhangjiajie (Zhong, Deng, \& Xiang, 2008). Hal ini menunjukkan bahwa adanya upaya untuk mengelola lingkungan secara lebih berkelanjutan juga berdampak pada peningkatan kehidupan ekonomi masyarakat.

Berbagai studi mengenai penerapan konsep pembangunan berkelanjutan dalam mengelola kawasan konservasi mampu memberi dampak positif bagi keberlanjutan kawasan dan kehidupan masyarakat sekitar baik secara ekologis, sosial, dan ekonomi. Untuk itu, artikel bertujuan untuk mengetahui arahan dan strategi pengembangan yang direncanakan dalam penataan kawasan hutan lindung. Studi dilakukan dengan mengambil lokasi pada KHLSW dan KHLSM Kota Balikpapan dalam upaya menjaga kelestarian hutan lindung pada dua kawasan tersebut. Aspek kelestarian lingkungan menjadi fokus utama dari penyusunan rencana tata ruang kawasan hutan lindung namun tidak mengabaikan pertimbangan aspek sosial dan ekonomi dan tetap melihat konsep pembangunan sebagai sebuah konsep yang saling berkaitan.

\section{Metode}

Analisis dilakukan dengan cara membandingkan strategi penataan ruang yang meliputi pengaturan zonasi dan aktivitas kawasan hutan lindung Kota Balikpapan dengan indikator pembangunan berkelanjutan yang telah ditetapkan oleh Comission of Sustainable Development UN dan disesuaikan dengan karakteristik Negara Indonesia. Hasil perbandingan yang dilakukan akan dijadikan dasar pemahaman toritis dalam pendeskripsian strategi pengembangan wilayah yang digunakan untuk mereduksi ancaman lingkungan yang terjadi.

Ruang lingkup materi dibatasi pada indikator pembangunan berkelanjutan pada aspek sumber daya air tawar, keanekaragaman hayati dan pembangunan ekonomi. Indikator keanekaragaman hayati, meliputi konservasi kawasan daratan serta keanekaragaman satwa dan tumbuhan. Indikator pembangunan ekonomi diwakili aspek pengembangan pariwisata. Pembatasan indikator yang digunakan bertujuan untuk mendapatkan hasil yang relevan dengan karakteristik huta lindung di Kota Balikpapan. Hasil arahan pengembangan kawasan wisata hutan lindung di Kota Balikpapan akan dibandingkan dengan best practice pengelolaan hutan lindung yang ada di daerah lain yang dianggap telah berhasil menjaga kelestarian hutannya dan menjadi sumber pemasukan bagi pemerintah setempat dan masyarakat. 


\section{Hasil dan Pembahasan}

Kelestarian kawasan hutan lindung di Kota Balikpapan saat ini mulai terancam dengan semakin maraknya aktivitas masyarakat di sekitar kawasan hutan lindung. Kawasan hutan lindung di Kota Balikpapan juga dihuni oleh sejumlah kategori warga, yaitu warga yang memiliki KTP Balikpapan, tanpa KTP, dan penduduk dari luar kawasan. Saat ini pengelolaan hutan kemasyarakatan hanya diberikan pada kelompok warga setempat yang memiliki KTP Balikpapan. Meskipun terdapat beberapa kelompok pengelola hutan kemasyarakatan yang mendapatkan izin dari Menteri Kehutanan, namun pengelolaan hutan kemasyarakatan diberikan kepada sepuluh kelompok tani setempat sehingga rawan penyalahgunaan.

Permasalahan alih fungsi pemanfaatan hutan di kawasan lindung Kota Balikpapan mengancam kelestarian kawasan hutan lindung Sungai Wain dan Sungai Manggar. Selain permasalahan tersebut, permasalahan lain yang juga mengancam kelestarian kawasan hutan lindung, antara lain:

a) Incaran Pembalak liar;

b) Maraknya ekspansi modal dan pembangunan, yaitu mulai banyak muncul industri dan pemukiman, seperti kawasan industri Kariangau yang hanya berjarak sekitar dua hingga tiga kilometer dari hutan lindung;

c) Aktivitas tambang batubara;

d) Rencana pembangunan jembatan Pulau Balang, dengan dibangunnya jembatan Pulau Balang yang sangat berpengaruhkarena akan membuka akses ke hutan lindung.

Pembukaan kawasan industri dan penambangan memberikan konsekuensi kebutuhan lahan untuk sarana penunjang aktivitas seperti kawasan hunian untuk pekerja, sarana pendidikan, sarana kesehatan serta sarana penunjang lainnya yang dikhawatikan pengembangannya dapat mengganggu kelestarian kawasan hutan lindung mengingat jaraknya yang sangat dekat. Kawasan strategis pendidikan turut mengancam kelestarian hutan lindung. Pengembangan kampus akan memicu pengembangan kawasan di sekitarnya. Apabila pembangunan kawasan sekitar kampus tidak diatur, dikhawatirkan pengembangannya akan mengganggu kelestarian hutan lindung.

Dilihat dari sisi sosial dan ekonomi, peran serta masyarakat dalam usaha menjaga dan mengelola hutan lindung dirasa belum optimal. Hal ini dapat dilihat dengan masih maraknya alih fungsi lahan yang dilakukan masyarakat sekitar dengan tujuan mendapatkan nilai ekonomi dari lahan tersebut. Berdasarkan Undang-Undang Nomor 32 Tahun 2009 tentang Perlindungan dan Pengelolaan Lingkungan Hidup disebutkan bahwa "masyarakat memiliki hak dan kesempatan yang sama dan seluas-luasnya untuk berperan aktif dalam perlindungan dan pengelolaan lingkungan hidup." Dengan demikian, peran serta masyarakat dalam pengelolaan hutan lindung perlu diperkuat namun juga perlu ditata agar lebih memberikan nilai manfaat sosial, ekonomi dan lingkungan sekaligus.

\section{Arahan Pengembangan Kawasan Hutan Lindung}

Untuk dapat mengurangi ancaman, dalam RDTR kawasan strategis hutan lindung Kota Balikpapan memuat arahan pengembangan KHLSW dan KHLSM. Konsep pengembangan KHLSW dalam perencanaan kedepan difokuskan untuk "Mewujudkan Hutan Lindung Sungai Wain sebagai Laboratorium Hutan Tropis". Adapun beberapa arahan pengembangan yang akan dilakukan dalam perencanaan kawasan lindung Sungai Wain, yaitu:

1. Pengembangan sarana dan prasarana yang menunjang pemanfaatan kawasan sebagai kawasan wisata alam, wisata pendidikan lingkungan hidup, serta kegiatan penelitian flora fauna khas Kalimantan; 
2. Melakukan upaya pencegahan alih fungsi lahan melalui melarang kegiatan pertanian; melarang kegiatan kehutanan, industri, perdagangan dan jasa perkantoran dan perumahan, serta kegiatan ruang terbuka non hijau. Untuk kegiatan yang diperbolehkan namun terbatas adalah kegiatan pariwisata, kegiatan eksplorasi dengan syarat $\mathrm{KDB}$ maksimal 30\%. Untuk kegiatan yang diperbolehkan adalah kegiatan ruang terbuka hijau berupa buffer zone hutan lindung dan perluasan hutan lindung.

Konsep pengembangan kawasan hutan lindung Sungai Manggar dalam perencanaan difokuskan untuk "Mewujudkan Kawasan Hutan Lindung Sungai Manggar Sebagai Kawasan yang Berperan Penting dalam Menjaga Kelestarian Penyediaan Sumber Daya Air Baku Permukaan dan Air Tanah”. Adapun beberapa arahan pengembangan yang akan dilakukan dalam perencanaan kawasan lindung Sungai Wain ini berdasarkan Studi Kajian Sumber Pencemaran Domestik di Sepanjang DAS dan Sub DAS Manggar adalah:

1. Pembatasan pembangunan permukiman yang terdapat di kawasan lindung atau konservasi sebagai upaya pengendalian pemanfaatan ruang di kawasan lindung Sungai Manggar.

2. Pembangunan kawasan permukiman disesuaikan dengan sistem pengelolaan limbah dalam upaya mempertahankan Sungai Manggar sebagai penyedia sumber air baku. Permukiman berkepadatan rendah hingga sedang menggunakan sistem pengelolaan limbah on site. Permukiman dengan kepadatan tinggi menggunakan system off site.

\section{Indikator Pembangunan Berkelanjutan}

Guna mengetahui kesesuaian arahan pengembangan kawasan hutan lindung dengan konsep pembangunan berkelanjutan, maka dibutuhkan sebuah acuan. Adapun indikator pembangunan berkelanjutan (CSD, 2015), meliputi :

a. Usaha mempertahankan luasan kawasan konservasi daratan. Kawasan konservasi daratan meliputi kawasan hutan cagar alam, suaka margasatwa, taman nasional, taman wisata alam dan taman hutan raya.

b. Usaha melindungi spesies satwa dan tumbuhan. Pemerintah Indonesia melalui Kementerian Kehutanan berusaha untuk menjaga kelestarian spesies satwa dan tumbuhan yang terancam punah.

c. Usaha pengembangan kawasan pariwisata. Sektor pariwisata merupakan sektor yang penting untuk dikembangkan, selain karena Indonesia memiliki potensi di sektor tersebut. Sektor pariwisata dianggap sektor yang mampu bertahan terhadap ancaman krisis ekonomi.

d. Usaha meningkatkan kualitas dan kuantitas air bersih. Air bersih merupakan faktor sentral dalam pembangunan berkelanjutan.

\section{Strategi Penataan Ruang untuk Mereduksi Ancaman}

Berdasarkan penjabaran sebelumnya, arahan pengembangan yang tertuang dalam RDTR Kawasan strategis hutan lindung di Kota Balikpapan sudah sesuai dengan indikator pembangunan berkelanjutan yang merupakan acuan dalam penyusunan RDTR kawasan strategis Kota Balikpapan secara makro. Peraturan zonasi yang ditetapkan sebagai pencegahan alih fungsi lahan ditetapkan guna melindungi kawasan hutan lindung dari aktivitas industri dan penambangan. Dengan semakin meningkatnya kebutuhan ruang untuk sarana dan prasarana penunjang kegiatan, peraturan zonasi ini menjadi panduan dalam pembangunan ke depan dan diharapkan dapat mereduksi ancaman dari pengembangan di sekitarnya. Pelarangan kegiatan pertanian, melarang kegiatan kehutanan, industri, perdagangan dan jasa perkantoran, perumahan, serta kegiatan ruang terbuka non- 
hijau dimaksudkan untuk menjaga kawasan hutan lindung dari ancaman pengembangan di sekitarnya.

Pembatasan pembangunan permukiman di kawasan lindung atau konservasi menjadi langkah preventif sejalan dengan peningkatan aktivitas kawasan dan penduduk pendatang. Kehadiran para pendatang tentunya diikuti dengan kebutuhan tempat tinggal bagi para pendatang tersebut. Hal yang sama juga berlaku untuk kawasan pendidikan. Pengembangan kawasan pendidikan tentu akan memicu perkembangan kawasan di sekitarnya. Keberadaan mahasiswa pendatang akan meningkatkan kebutuhan lahan untuk tempat tinggal dan sarana penunjang lainnya.

Kegiatan pariwisata alam yang masih diperbolehkan di kawasan hutan lindung menjadi wujud usaha peran serta masyarakat untuk dapat menjaga dan mengelola hutan lindung. Selain sebagai sarana edukasi, dicanangkannya hutan lindung sebagai kawasan wisata juga dapat memberikan nilai ekonomi bagi masyarakat sekitar. Dengan rasa kepemilikan bersama hutan lindung, diharapkan aktivitas alih fungsi lahan sebagai perkebunan dan pertanian yang dilakukan masyarakat dapat berkurang mengingat masyarakat telah memiliki mata pencaharian alternatif dari sektor pariwisata.

Belajar dari best practice dari contoh kasus pada kawasan hutan lindung di China berdasarkan penelitian Zinda (2015), Li et al. (2013), Yeh (2009), dan Zhong et al. (2008) mengindikasikan bahwa pemerintah daerah dapat meningkatkan pengelolaan kawasan hutan lindung secara lebih baik lagi. Hutan lindung yang mampu dikelola dengan baik bukan hanya untuk meningkatkan pendapatan dari sektor pariwisata, tetapi juga untuk menjaga kelestarian kawasan hutan lindung itu sendiri. Dengan sistem kepemilikian tanah yang dimiliki penuh oleh masyarakat, tentu pemerintah akan kesulitan untuk melakukan relokasi masyarakat, Namun, pengendalian aktivitas masyarakat masih bisa dilakukan dengan beragam proses kegiatan partisipatif. Pemerintah daerah dapat menjadi koordinator pengembangan kawasan wisata serta menetapkan aturan dan larangan terkait usaha yang dilakukan masyarakat dan level pengelolaan masih dilakukan oleh masyarakat sekitar. Lebih lanjut, pemeritah juga dapat memberikan insentif untuk meningkatkan kapasitas hidup masyarakat sebagai wujud apresiasi. Namun demikian, insentif yang diberikan harus berkorelasi dengan program konservasi yang dilakukan pada kawasan konservasi (Karki, 2013).

Strategi bagi hasil usaha juga dapat dilakukan pemerintah dengan masyarakat dengan besaran yang dibicarakan melaui forum-forum warga. Usaha yang dilakukan oleh pemerintah bukan hanya menjamin kelestarian hutan lindung dan mengembangkan kawasan wisata, namun juga akan mengedukasi masyarakat bahwa keberadaan hutan lindung sangat penting bagi masyarakat itu sendiri. Strategi pengembangan kawasan hutan lindung di Kota Balikpapan terlihat pada Tabel 1.

Tabel 1. Strategi Pengembangan Kawasan Hutan Lindung di Kota Balikpapan

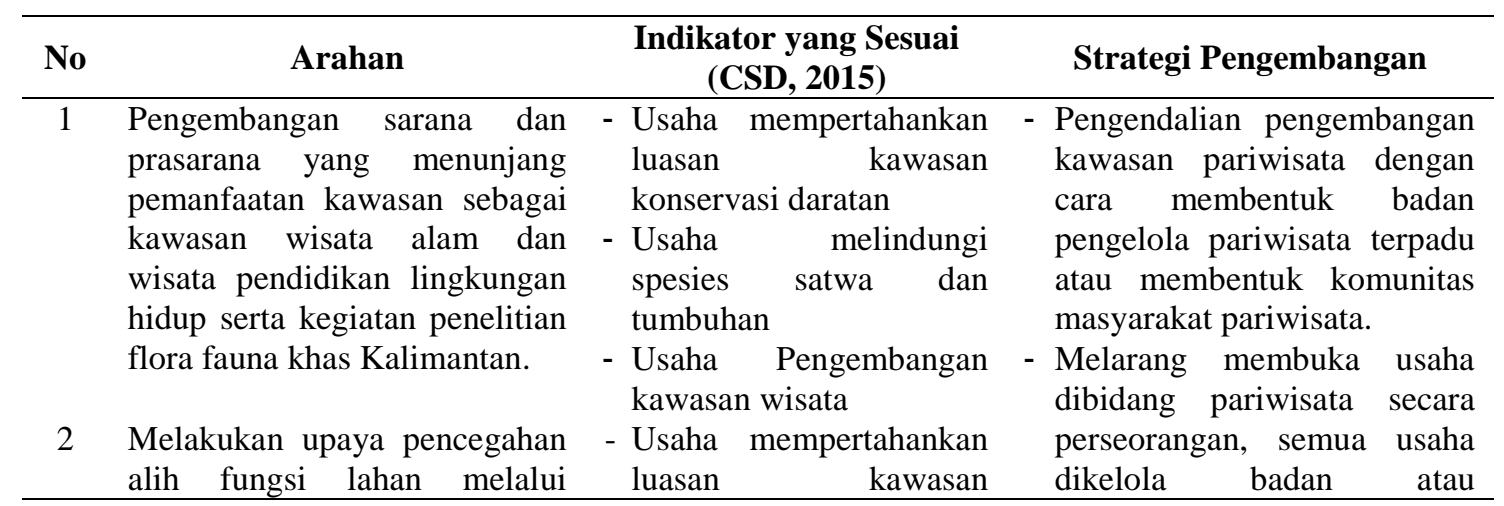




\begin{tabular}{|c|c|c|c|}
\hline No & Arahan & $\begin{array}{c}\text { Indikator yang Sesuai } \\
(\mathrm{CSD}, 2015)\end{array}$ & Strategi Pengembangan \\
\hline 4 & $\begin{array}{l}\text { melarang kegiatan pertanian; } \\
\text { melarang kegiatan kehutanan, } \\
\text { industri, perdagangan dan jasa } \\
\text { perkantoran dan perumahan; } \\
\text { serta kegiatan ruang terbuka } \\
\text { non-hijau. Untuk kegiatan } \\
\text { yang diperbolehkan namun } \\
\text { terbatas adalah kegiatan } \\
\text { pariwisata; kegiatan eksplorasi } \\
\text { dengan syarat KDB maksimal } \\
\text { 30\%. Untuk kegiatan yang } \\
\text { diperbolehkan adalah kegiatan } \\
\text { ruang terbuka hijau berupa } \\
\text { buffer zone hutan lindung; dan } \\
\text { perluasan hutan lindung. } \\
\text { Pembatasan pembangunan } \\
\text { permukiman yang terdapat di } \\
\text { kawasan lindung/ konservasi } \\
\text { sebagai upaya pengendalian } \\
\text { pemanfaatan ruang di kawasan } \\
\text { lindung Sungai Manggar. } \\
\text { Pembangunan kawasan } \\
\text { permukiman kan disesuaikan } \\
\text { dengan sistem pengelolaan } \\
\text { limbah sebagai upaya } \\
\text { mempertahankan sungai } \\
\text { Manggar sebagai penyedia } \\
\text { sumber air baku. Permukiman } \\
\text { dengan kepadatan rendah } \\
\text { sampai sedang menggunakan } \\
\text { system pengelolaan limbah on } \\
\text { site sedangkan permukiman } \\
\text { dengan berkepadatan tinggi } \\
\text { menggunakan system off site. }\end{array}$ & $\begin{array}{l}\text { Usaha mempertahankan } \\
\text { luasan kawasan konservasi } \\
\text { daratan }\end{array}$ & 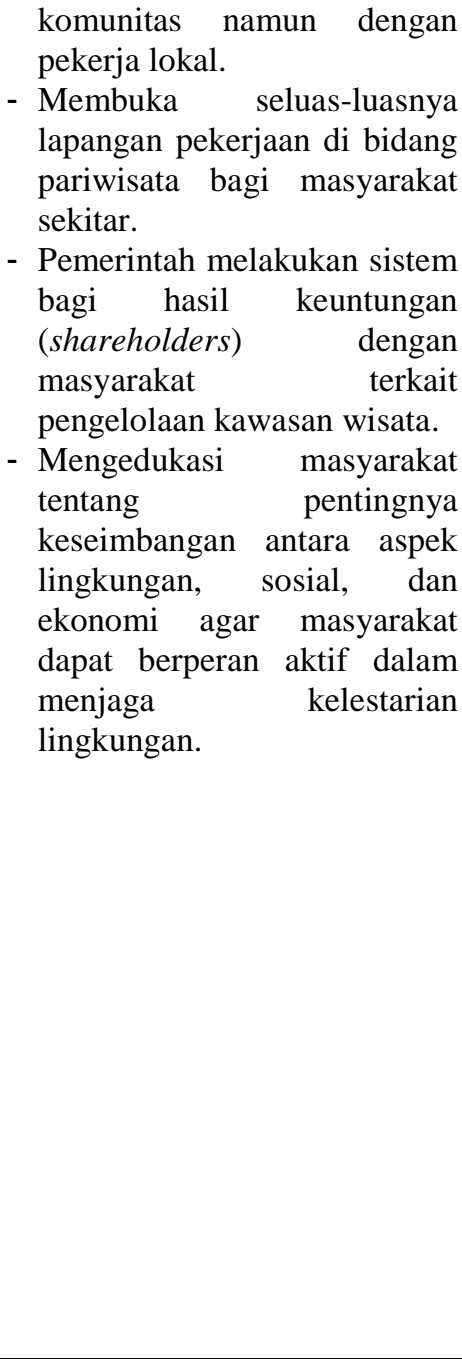 \\
\hline
\end{tabular}

\section{Kesimpulan dan Rekomendasi}

Konsep pembangunan berkelanjutan yang menjadi konsep makro dalam penyusunan RDTR kawasan strategis sudut pandang sosial budaya dan lingkungan hidup Kota Balikpapan dapat diterjemahkan secara baik pada arahan pengembangan yang dirumuskan pada RDTR kawasan strategis hutan lindung. Hal ini dapat dilihat dari adanya arah perencanaan yang mengarah pada pembangunan berkelanjutan. Konsep pengelolaan kawasan hutan lindung melalui konsep developmental conservation mampu memberikan perlindungan bagi kelestarian hutan lindung karena adanya peraturan pemerintah dalam untuk mengatur aktivitas wisata yang diperbolehkan, disamping menghasilkan nilai ekonomis dan memperkuat kondisi sosial masyarakat sekitar karena adanya upaya pelibatan masyarakat sebagai stakeholder utama dalam pengembangan pariwisata. Strategi penataan kawasan yang ditetapkan juga dirasa mampu untuk mereduksi ancaman yang ada. Usaha pemerintah untuk dapat mengedukasi masyarakat menjadi peranan kunci dalam keberhasilan penerapan strategi pengelolaan kawasan hutan lindung. 


\section{Memberdayakan Rencana Detail Tata Ruang (RDTR) Kawasan Strategis Hutan Lindung Sungai Wain ...}

\section{Daftar Pustaka}

Apriyanto, H., Eriyatno, Rustiadi, E., \& Mawardi, I. (2015). Status berkelanjutan Kota Tangerang Selatan-Banten dengan menggunakan Key Performance Indicators. J. Manusia dan Lingkungan, 22(2), 260-270.

Cleveland, C. J., \& Kubiszewski, I. (2007). United Nations Conference on Environment and Development (UNCED), Rio de Janiero, Brazil, 2007 Encyclopedia of Earth. Retrieved from http://www.eoearth.org/article/United_Nations_Conference_on_Environment_and_Development_(U NCED),_Rio_de_Janeiro,_Brazil\#gen0.

Comission on Sustainable Development (CSD). (2015). Decisions: 8th session of the comission on sustainable development. Retrieved from https://sustainabledevelopment.un.org/index.php?menu=1416.

Diaz, R. A. (2011). Planning for sustainable development: Strategic alignment in Peruvian regions and cities. Futures, 43(8), 908-918. doi:10.1016/j.futures.2011.06.014.

Fauzi, A., \& Oxtavianus, A. (2014). Pengukuran pembangunan berkelanjutan di Indonesia. MIMBAR, 30(1), 4252 .

Karki, S. T. (2013). Do protected areas and conservation incentives contribute to sustainable livelihoods? A case study of Bardia National Park, Nepal. Journal of Environmental Management, 128, 988-999. doi:10.1016/j.jenvman.2013.06.054

Lama, A. K., \& Job, H. (2014). Protected areas and road development: Sustainable development discourses in the Annapurna Conservation Area, Nepal. Erdkunde, 68(4), 229-250.

Li, Y., Li, W., Zhang, C., \& Fan, M. (2013). Current status and recent trends in financing China's nature reserves. Biological Conservation, 158, 296-300. doi:10.1016/j.biocon.2012.10.005.

Republik Indonesia. (2009). Undang-Undang Nomor 32 Tahun 2009 tentang Perlindungan dan Pengelolaan Lingkungan Hidup. Indonesia: Sekretariat Negara Republik Indonesia.

Romagosa, F., Eagles, P. F. J., \& Lemieux, C. J. (2015). From the inside out to the outside in: Exploring the role of parks and protected areas as providers of human health and well-being. Journal of Outdoor Recreation and Tourism, 10, 70-77. doi:10.1016/j.jort.2015.06.009.

Salim, E. (1992). Pembangunan berwawasan lingkungan. Jakarta: Yayasan LP3ES.

Sutamihardja. (2004). Perubahan lingkungan global. Bogor: Program Studi Pengelolaan Sumber Daya Alam dan Lingkungan, Sekolah Pascasarjana, IPB.

Yeh, E. T. (2009). Greening Western China: A critical view. Geoforum, 40, 884-894. doi:10.1016/j.geoforum.2009.06.004.

Zhong, L., Deng, J., \& Xiang, B. (2008). Tourism development and the tourism area life cycle model: A case study of Zhangiajie National Forest Park, China. Tourism Management, 29(5), 841-856. doi:10.1016/j.tourman.2007.10.002.

Zinda, J. A. (2015). Tourism dynamos: Selective commodification and developmental conservation in China's protected areas. Geoforum. Advance online publication. doi:10.1016/j.geoforum.2015.08.004. 